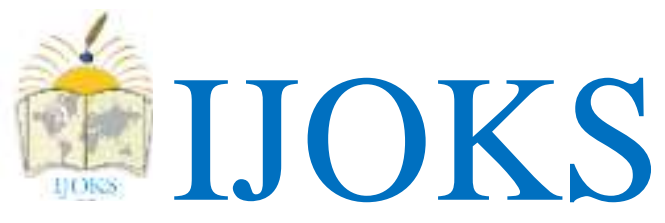

International Journal of Kurdish Studies

(ISSN:2149-2751)

3 (2), pp. $93-110$

http://www.ijoks.com

\title{
Different types of spelling errors made by Kurdish EFL learners and their potential causes
}

\author{
Ibrahim Abdulrahman AHMED
}

Received: Jan 17, 2017 Reviewed: May 31, 2017 Accepted: Jun 21, 2017

\begin{abstract}
The purpose of this study is to investigate various types of spelling errors and the causes of spelling inaccuracy of first year Kurdish college students found in their compositions. Participants are 40 Kurdish learners of English at two different universities, Koya University and Saladin University, who were studying English language and literature. The present study first displays general background about English writing system and definitions of related terms followed by an overview of Kurdish writing system and its orthography. In addition, differences between both languages' writing systems have been shown as is likely to be the cause of Kurdish learners' spelling mistakes. Spelling mistakes made by Kurdish college students are then classified into eight main categories and analysed statistically. The eight categories of English spelling mistakes incorporate Insertion, omission, substitutions, transposition, grapheme substitution, space inaccuracy, capitalisation and others. Despite lack of sufficient phonological and morphological knowledge in English the dissimilarity between English and Kurdish writing systems tends to be the main cause of spelling errors by first year Kurdish college students. It is significant for both students and instructors to be aware of the causes and types of English spelling mistakes so as to try to minimise them. It can be thought that knowing these causes would probably help not only English language learners but also its instructors to solve erroneous spellings to a large extent. Keywords: Spelling mistakes, Kurdish EFL learners, Kurdish writing system, English writing system, orthography
\end{abstract}

\section{Recommended citation:}

Ahmed I.A. (2017). Different types of spelling errors made by Kurdish EFL learners and their potential causes. International Journal of Kurdish Studies 3 (2), 93 - 110

\section{INTODUCTION}

Writing is one of the challenging skills for learners which includes several sub categories such as writing system, spelling, orthography and punctuation that pose difficulties for learners even for first language learners since they need be taught how to write unlike speaking skill that

\footnotetext{
${ }^{1}$ Koya University/ Koya/ Erbil/ Kurdistan Region/Iraq, Ibrahim.ahmed@ @oyauniversity.org
} 
can be acquired naturally in the first language. Like other learners of English, Kurdish learners are very likely to encounter numerous difficulties in learning English. Hence, these difficulties lead them to make various kinds of linguistic, morphological, phonological and orthographical errors. However, Corder (1981) thinks that these types of errors are the natural by-product of language learning. He also considers these errors as a significant clue of language learning progress. Thus, he suggests systematic analysis of learners' mistakes so as to understand their problems and needs and, in turn, design pedagogic methods and remedial strategies and plans accordingly.

Accurate spelling is desperately required in writing skill in order to convey messages efficiently. Hence, correct spelling is indispensable because one misspelling might spoil the meaning of an original message that a writer wants to convey (Fagerberg, 2006). Misspelling is one of the commonest mistakes that English as a second or foreign language (ESL/ EFL) learners encounter including Kurd EFL learners. As it can be argued that one of the most frequent errors in Kurd students' written productions is spelling errors. The majority of students keep committing the same spelling mistakes throughout their learning stages of English even after they are admitted to college which often makes their written works difficult to understand as well as it probably hinders them to write in English with confidence due to fear of making spelling mistakes. As Smedley (1983) considers that spelling mistakes influenced the clarity and intelligibility of written works in a negative way and thus in damages communication between the author and the reader.

\subsection{Basic concepts and terms in writing system}

The basic entity in written language is called 'grapheme' which is defined by Crystal (2003) as 'the smallest unit in the writing system capable of causing a contrast in meaning' (p. 257). writing system is the overall system of written languages in which two distinct meanings has been attributed to the term 'writing system' by Cook and Bassetti (2005), the first general meaning refers to "the terms 'scripts' and 'orthography"' (p. 3). Hence, the writing system can be described in this sense as 'a set of visible or tactile signs used to represent units of language in a systematic way' (Coulmas, 1996, p. 560). While, orthography is defined by Cook and Bassetti (2005) as 'the set of rules for using a script in a particular language' (p. 3). In addition script is defined by Coulmas (2003) as 'the graphic form of the units of a writing system' (p. 35). In The second meaning, the two terms of 'orthography' and 'writing system' overlap as the former is described as 'the set of rules employed in a particular language for spelling, punctuation etc.,' (Cook and Bassetti, 2005, p. 3). Thus, in this sense the term of 'writing system' refers to a specific language such as 'the English writing system' or 'the Kurdish writing system' and so on. Nevertheless, some researchers, for instance, Sampson (1985) and Sproat (2000) state that the two terms of 'orthography' and 'writing system' might be utilised interchangeably. However, in this study, the term writing system refers to the sense that Cook (2004) defines as 'the way that a particular language and its users systematically employ writing' (p. 27). 
Languages are written in a variety of scripts, some of them share the same script, whereas, some others use different scripts to represent their writing systems. As Sampson (1985) states that 'one language may be written in different scripts, and the same script may be used to write different languages' (p. 21). Script is not a language itself but it means for visualising examples of a language (ibid). Catach (1988) cited in Perfetti and Charles (1997) defines scripts as a 'sets of discrete, articulated and arbitrary signs, which enable any constructed message to be transmitted without necessarily using natural means' (p. 243). Another term which is used as a unit in language systems is a letter which is related to one of the units of script in which together form 'the elements of various writing systems' (Sampson, 1985, p. 22). Hence alphabetical languages can be written in each other's scripts or letters but not with symbolic languages i.e. English can be written in Arabic or Russian letters but it is unacceptable to be written in Japanese or Chinese scripts as the scripts of the latter two languages are called 'characters'.

According to Baron (2005) and Birch (2007) all languages of the world can be fallen into three categories in terms of their writing systems which are logographic, syllabic and alphabetic systems. An example of the logographic writing system would be the kanji system in Japanese in which 'one symbol represents the concept or meaning of an individual word or part of a word' (Birch, 2007, p. 16). Whereas, syllabic writing exemplifies a system in which the 'symbols represent the syllables of the language' (Lado, 1964, p. 18), however, when one symbol links to one sound, this is known as an alphabetic writing system. Hence, both English and Kurdish are practising alphabetic writing systems according to the above description.

\section{A general background about Kurdish writing system}

Kurdish language consists of two main dialects which are Sorani and Kurmanji, in which each one of them utilises a different writing system and orthography, as the former use modified Arabic scripts and the latter utilises modified Latin scripts for their writing systems (Matras and Reershemius, 1991; Soltani, 2005). Although, both writing systems are in use, they both have some shortcomings in corresponding to all Kurdish Phonemes as in modified Arabic the phoneme /i/ is not represented, and the modified Latin does not have standard scripts for four letters and phonemes such as $(\dot{\varepsilon} \bullet \mathcal{} \bullet \tau$ and ) which are considered as foreign phonemes borrowed from Arabic (Daneshfar et al., 2009). Hence, there has been quite a long controversy over the issue of which writing system need to be adopted in order to unify the Kurdish dialects via one standard writing system. The Sorani dialect is used in Kurdish speaking areas in Iraq and Iran. whereas, the Kurmanji dialect is mainly used in Kurdish speaking areas in Syria and Turkey which is used by three-quarters of all Kurds (Abdullah and Aram, 2004). However, Sorani Kurds have had more opportunities to study and receive education in their language than the Kurmanji ones as from the early 1920s Kurdish has formally become the language of instruction in educational institutions in the Kurdish speaking areas in Iraq (now known an Kurdistan Region), whereas such literary instruction was not and has not been allowed formally in Syria, Turkey and Iran. Thus, the Sorani dialect has become the standard dialect in Iraqi Kurdistan and the only Kurdish dialect, which is written in modified Arabic scripts, taught and learnt formally in public educational institutions (Rahimpour and Dovaise, 2011). As the focus of this study is on Sorani dialect and its writing system, thus the term Kurdish refers to this dialect in this paper henceforth. 
In order to have a better understanding of the underlying factors of spelling errors made by Kurdish learners of English and the role of first language interference in second language learning, The Kurdish writing system needs to be further explained. The Kurdish alphabet consist of 33 letters which includes 25 consonants and eight vowels corresponding to 36 phonemes without counting diphthongs. Kurdish is written from right to left since it is based on Arabic-Persian alphabet. The Kurdish writing system is an alphabetic, sound based and a phonetic language as there are one two one correspondence between letters and phonemes with a fewer exceptions such as /i/ phoneme, which is similar to schwa /ə/ in English, is not represented (Mc Carus, 1992). Since the Arabic alphabet does not have enough letters or scripts to represent all Kurdish phonemes, some letters have been borrowed from Persian such as p, ç and g/ respectively (Hassanpour, 1992). This borrowings did not satisfy the Kurdish phonemes and thus Kurdish intellectuals produced certain letters by adding some subscript dots and diacritics to the existing Arabic letters which were near the Kurdish phonemes so as to represent the intended phonemes in Kurdish such as adding two dots to $\dot{e} / \mathrm{f} /$ to form to represent $/ \mathrm{v} /$ phoneme and adding diacritic to velar $\mathrm{J} / \mathrm{l} /$ and flap $\mathrm{J} / \mathrm{r} /$ to form $\mathrm{J}^{\mathrm{p}}$ palatal /í/ and thrill $\lrcorner / \check{r} /$ (ibid). Hence, the Kurdish writing system can be considered shallow in terms of 'orthographic depth' as there is direct correspondence between phonemes and letters with a very few exceptions just like Finnish and Serbo-Croatian languages which are illustrated as near the shallow in (Cook, 2004). Therefore Kurdish unlike English does not require phonetic transcription due to having one-to-one mapping trait between letters and phonemes which aid learners to write what they exactly say without memorising word forms or without ever seen a word before just by knowing individual letters.

\section{Types of spelling mistakes made by Kurdish college students}

Sample of spelling errors have been collected from first-year Kurdish college students' compositions, which were short paragraphs about three different topics of those students studying English as a foreign language in two different universities in Kurdistan Region. Among 120 students' samples only forty were chosen randomly in order to discover the number and types of spelling errors made by Kurdish college students in their short compositions which were about 50 to 100 words each. The selected samples were examined for errors and then all the misspelling words were registered and classified according to their types. The repeated misspelling of a particular word by the same student were counted only once, however if the same word was misspelled by different students it has been counted each time. In addition if there were more than one types of spelling errors in a word, it was recorded once in each students' samples for instance <langueg> can be classified under omission and substitution types of errors but it has been classified as one erroneous word under the category of (other).

The errors found in the selected samples' written works have been classified into eight categories by adapting the classification pattern from Wing and Baddeley (1980) and cook (2004) which are as follows:

1- Addition (insertion): when an extra letter are added to a word such as <verey> for <very> or <caluture> for culture

2- Omission: when a letter is deleted or missed from a word such as $\langle$ diffrent $\rangle$ for $\langle$ different $>$ and $<$ blak $>$ for $<$ black $>$ 
3- Substitution: when a letter is replaced by another one, such as $\langle$ picnik $>$ for $\langle$ picnic $>$

4- Transposition: when two neighbouring letters transposed, such as $\langle$ tow $\rangle$ for $\langle$ two $\rangle$

5- Grapheme substitution: "involving more than two letters but only a single cause, for example when an equivalent according to sound correspondence rules is substituted for the usual form, as in 'thort' for 'thought'" (Cook, 2004, p. 124)

6- Word space: when a compound word were separated with a space or where not word space left between words, such as <break fast $>$ for $<$ breakfast $>$ and $<$ alot $>$ for $<$ a lot $>$.

7- Capital: when a letter is capitalised unnecessarily or in a sentence or a when required capital letter is written in lower case for instance, $\langle\mathrm{i}\rangle$ for $\langle\mathrm{I}\rangle$ or $\langle\mathrm{My}$ ? for $\langle$ my $\rangle$ in a sentence.

8- Other: when an erroneous word cannot be classified under one particular given category or it has more than one type of spelling mistake in it such as <colegge> for <colleague $>$ or $<$ langueg $>$ for $<$ language $>$ as the latter contains both omission and substitution spelling error in it.

\subsection{Spelling error categories and their proportion in the collected samples}

In the process of scrutinising 40 compositions from the first year Kurdish university students, 233 spelling errors were identified. The average number of spelling mistakes made by Kurdish EFL learners are $5.8 \%$ for each one of them. The 233 spelling errors have been classified into eight main categories and the rate of each type have be shown in the following table (Table 1).

Table 1 the types and the proportion of spelling errors by Kurdish EFL learners

\begin{tabular}{|c|c|c|c|c|c|c|c|c|c|}
\hline 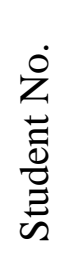 & 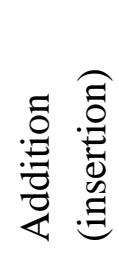 & 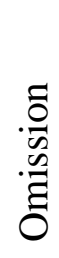 & 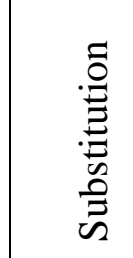 & 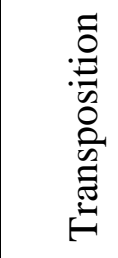 & 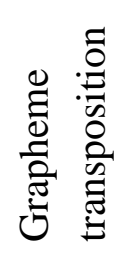 & $\begin{array}{l}\ddot{\tilde{E}} \\
\tilde{0} \\
0 \\
0 \\
0 \\
\dot{0}\end{array}$ & 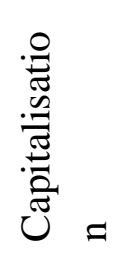 & $\frac{\mathscr{d}}{\stackrel{ \pm}{0}}$ & 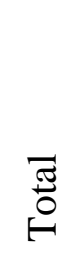 \\
\hline 1 & & 3 & 1 & & & & 2 & & 6 \\
\hline 2 & 1 & 1 & & 1 & & 1 & 1 & & 5 \\
\hline 3 & 1 & 2 & 2 & & & & & & 5 \\
\hline 4 & 1 & 2 & 1 & 1 & & & 1 & 1 & 7 \\
\hline 5 & 1 & 1 & 1 & 1 & & & & 1 & 5 \\
\hline 6 & & 1 & 1 & & & & 2 & & 4 \\
\hline 7 & & 2 & 1 & & & 1 & 1 & & 5 \\
\hline 8 & 1 & & 1 & & & 1 & 1 & & 4 \\
\hline
\end{tabular}




\begin{tabular}{|c|c|c|c|c|c|c|c|c|c|}
\hline 9 & 1 & & & & 1 & 1 & 1 & & 4 \\
\hline 10 & 1 & 1 & 1 & & & 1 & 1 & & 5 \\
\hline 11 & & 1 & 2 & & & 1 & 1 & & 5 \\
\hline 12 & 1 & 1 & & & 1 & 1 & 1 & & 5 \\
\hline 13 & & 1 & 1 & & & 1 & 3 & & 6 \\
\hline 14 & & 2 & & & 1 & 1 & & 1 & 5 \\
\hline 15 & 1 & 1 & & & & 1 & 1 & & 4 \\
\hline 16 & & 2 & | & & & 1 & 1 & & 4 \\
\hline 17 & & 2 & 2 & 1 & & 1 & & & 6 \\
\hline 18 & 1 & 1 & 1 & & 1 & & 2 & & 6 \\
\hline 19 & & 2 & 1 & & 1 & 1 & 1 & 1 & 7 \\
\hline 20 & & 1 & 2 & & & & 1 & & 4 \\
\hline 21 & & 2 & 1 & 1 & & 1 & 3 & 1 & 9 \\
\hline 22 & & 1 & 2 & & 1 & & & 1 & 5 \\
\hline 23 & & 2 & & & & 3 & 1 & & 6 \\
\hline 24 & 1 & 4 & 1 & & & & & 1 & 6 \\
\hline 25 & & 2 & & 2 & 1 & 2 & 1 & & 8 \\
\hline 26 & & & 2 & & 1 & 1 & 1 & 1 & 6 \\
\hline 27 & & 2 & 1 & & & 1 & 2 & & 6 \\
\hline 28 & & 1 & 1 & & & 1 & 2 & & 5 \\
\hline 29 & & 1 & 3 & 1 & & & 1 & & 6 \\
\hline 30 & & 2 & 2 & & & 1 & 1 & & 6 \\
\hline 31 & 2 & 2 & & & & & 1 & & 7 \\
\hline 32 & & 2 & 2 & & 1 & 2 & & & 7 \\
\hline 33 & 2 & 2 & & & & & 4 & & 8 \\
\hline 34 & 2 & 1 & 1 & & & 1 & 1 & & 6 \\
\hline 35 & & & 1 & 1 & 2 & & 3 & & 7 \\
\hline 36 & 1 & 1 & 3 & & & 2 & & 2 & 9 \\
\hline 37 & 1 & 2 & & 1 & & 2 & 1 & & 7 \\
\hline 38 & & 2 & 2 & & & 1 & & 1 & 6 \\
\hline 39 & & 2 & & & & 2 & & & 4 \\
\hline 40 & & 1 & 1 & & & 2 & 2 & 1 & 7 \\
\hline Total & $\begin{array}{l}20 \\
8.6 \%\end{array}$ & $\begin{array}{l}59 \\
25,3 \%\end{array}$ & $\begin{array}{l}41 \\
17.6 \%\end{array}$ & $\begin{array}{l}10 \\
4.3 \%\end{array}$ & $\begin{array}{l}11 \\
4.7 \%\end{array}$ & \begin{tabular}{|l|}
35 \\
$15 \%$ \\
\end{tabular} & $\begin{array}{l}45 \\
19 \%\end{array}$ & $\begin{array}{l}12 \\
5 \%\end{array}$ & 233 \\
\hline
\end{tabular}


In Figure 1 below the proportions of the main eight types of spelling errors made my Kurdish EFL learners have been shown.

Figure 1 the rate of eight spelling errors

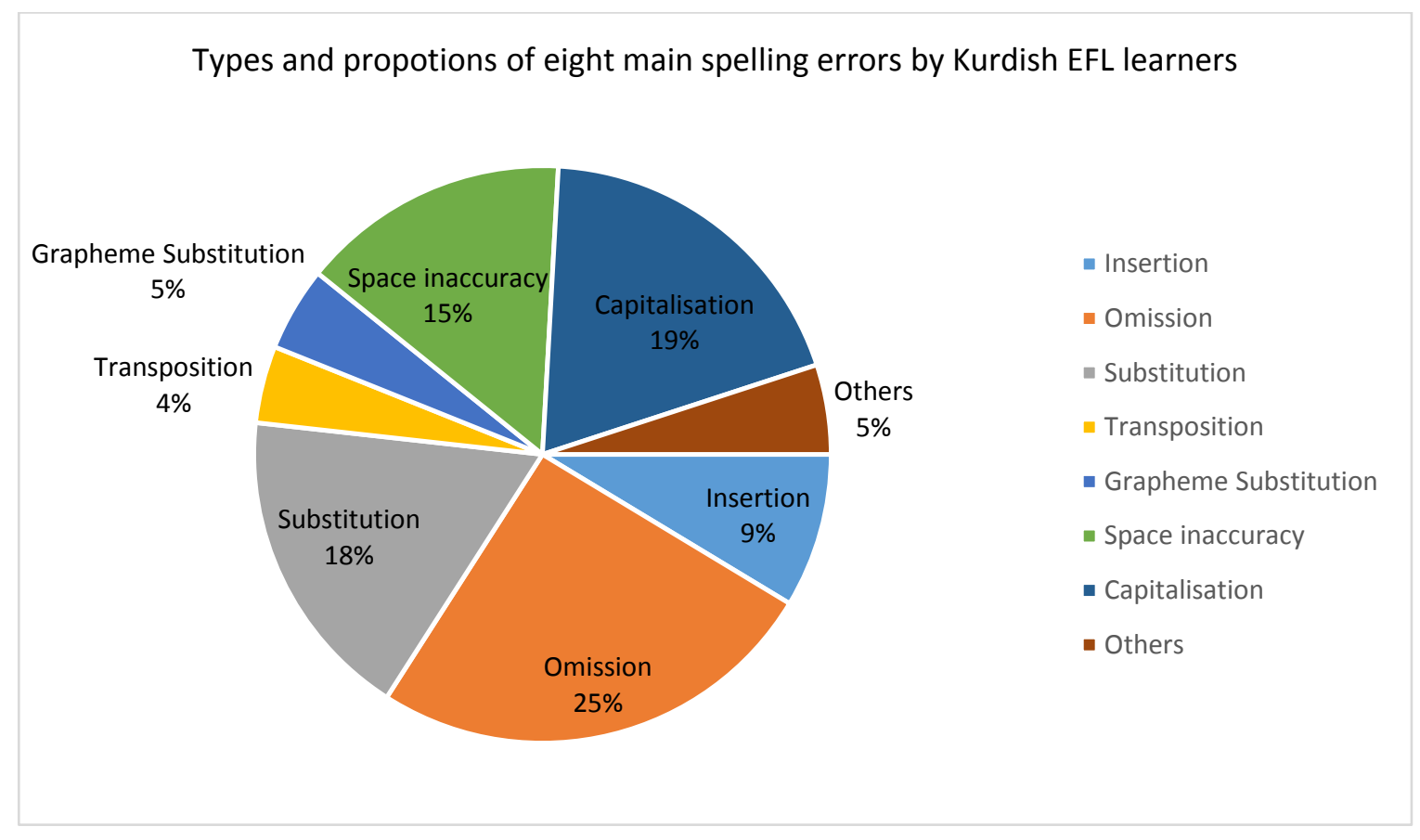

Figure 1 demonstrates that the commonest type of spelling errors made by Kurdish EFL learners is 'omission' (25.3\%) such as <suny> for <sunny> or <befor> instead of (before) followed by 'capitalisation' (19\%), it is worth mentioning that Kurdish students made high rate of capitalisation mistakes especially they have been negligent in capitalising the days of the week and the names of months such as <friday> for <Friday> or <march> for <March> or sometimes they did the opposite such capitalising a word in the middle of a sentence or a letter in the middle of a word $\langle$ cLoths $\rangle$ for $\langle$ cloths $\rangle$ or $\langle$ My $\rangle$ instead of $\langle$ my $\rangle$. This was followed by 'substitution' $(18 \%)$ as in $<$ ferst $>$ for $<$ first $>$. In fourth position was 'space inaccuracy' $(15 \%)$ for instance < anice> for <a nice> or <some times> for <sometimes>. Both categories of 'grapheme substitution' and 'other' were the same in proportion (5\%) and examples for them respectively are as in <bleim > for <blame $>$ and $<$ faivurat $>$ for $<$ favourite $>$. Transposition was 
the least type of spelling errors found in samples of Kurdish students' written works which was (4\%) the most frequent example of this type is in this study was <friend > for <friend $>$.

\section{The potential causes of English spelling mistakes}

Many studies have been conducted on English as a second and foreign language (ESL/EFL) learners of various language backgrounds, so as to identify different types of spelling mistakes and determine likely causes of their spelling errors. Most of these studies emphasise the premise the commonest cause of spelling mistakes by EFL or ESL learners is due to irregularity of English writing system (Al-Hassan, 2011; Al-Jarf, 2010; Gunian, 2012; Fagerberg, 2006; Jayousi, 2011). In addition, the difficulty of English spelling is attributed to the lack of correspondence between sound and spelling or phoneme and grapheme of the language (Altmann and Fengxiang 2008; Henderson, 1981; Perfetti et al., 1997). Some example of inconsistency in English writing system are as follows: firstly, one letter may represent various phonemes such as letter (a) in <dame, bad, task, all, village and many> and thus Foster (1992) states that English is orthographically deep. Secondly, different letters might represent one phoneme such as, <to too, two, though, threw, clue and shoe>. Thirdly, a set of letters together represent a single phoneme as in <change, shall, physics, nation, the, three>. More inconsistencies are there in English which requires its learners to memorise certain word forms and pay further attention to them despite knowing its orthographic rules particularly regarding silent letters as in <doubt, light, sign, knife> and so forth. Moreover, There are other causes which makes second language (L2) learners commit spelling mistakes such as linguistic differences between English and the learner's own language (Brown 2000; Saville-Troike, 2006; Swan and Smith, 2001). These causes stimulate spelling errors due to difference in orthography, morphology and phonology of the two languages (Holligan and Johnston, 1991; Tonga et all, 2009). On the other hand, first language interference may also play a role in making spelling errors in English by transferring first language (L1) phonological and orthographic rules into English processing ((Akamatsu, 2003; Koda, 2005). For instance, due to lack of /p/ phoneme in Arabic, its learners of English might write <broblem> for <problem> (Cook, 2004). Similarly owing to absence of $/ 1 /$ and $/ \mathrm{r} /$ or /b/ and /v/ phonemes in Japanese, Japanese speakers might spell <biolin> instead of <violin> and <negrect> for <neglect> (Gunion, 2012). As in a study by Al-Jarf (2009) on Arab learners of English he found that $63 \%$ of spelling mistakes were phonological and $27 \%$ were orthographic ones, which support the view that most spelling errors are resulted in those causes mentioned above. This might possibly be the case with the sample students in this paper who are Kurdish EFL learners, in terms of L1 interference and linguistic differences between English and Kurdish as well as the phoneme grapheme correspondence between the two languages.

This study seeks to investigate spelling mistakes made by first year Kurdish college students and classifying their spelling errors and show the potential causes of the occurrence of different types of spelling errors in their written works. Analysing their spelling errors gives teacher and practitioner better insights into the causes and types of their spelling errors which may certainly be helpful for future spelling instructions and enable them to deal with spelling issue more appropriately. In the following part different types of spelling error will be analysed along with their causes. 


\subsection{Possible causes for the spelling errors by Kurdish EFL learner}

The difference between the English language and a learner's first language has seemed to be the main cause of spelling inaccuracy by L2 learners as it can be noticed in previous studies (Cook, 1997, 2004; Okada, 2005). Mispronunciation by L2 learners has also been identified an effecting factor for making spelling errors (Brown, 1988). Other causes which have already been recognised as possible causes for misspelling are first language interference (Brown, 1988; Cook, 1997, 2004), deficiency in knowledge of English spelling rules (Van Berkel 2005) and careless mistakes such as slip of the pen or writing in haste (Brown, 1988, Carney, 1994). Four possible causes has been identified for spelling errors made by Kurdish university students as follow:

\subsubsection{The difference between Kurdish and English writing systems and orthography}

Both English and Kurdish are sound based and alphabetic writing systems based on the definition of sound based writing system by Cook (2008) as they represent their spoken language form through both vowels and consonants. However, English writing system is based on Roman alphabets, whereas Kurdish writing system is based on Arabic-Persian alphabets (Matras and Reershemius, 1991) and thus the direction of English is form left to right but the Kurdish one is form right to left. Moreover, Using word space and capital letters are other differences between Kurdish and English writing systems which have caused problems for Kurdish college students investigated in this study as they made (19\%) of their spelling errors in the collected samples in either lack of capitalisation or unnecessary capitalisation of letters or words as in <friday> for <Friday>, as well as they made (15\%) spelling errors of space inaccuracy in which $(63 \%)$ of errors were lack of spaces and $(37 \%)$ were having extra spaces particularly between compound words such as <break fast $>$ for <breakfast $>$ and conversely, $<$ itis $>$ for <it is $>$. The reason behind committing such mistakes relates to the premise that in Kurdish writing system space is usually used between clauses and sentences as a chain of words can be annexed together to form a clause or a sentence without having a space between individual words and space is not as important it is in English. In terms of capitalisation it is peculiar to Roman alphabet-based languages as English is one of them, since it is not employed in Kurdish writing system and thus Kurdish EFL learners in this study seemed to have a problem with capitalising the first letter of proper names the days of the week and the names of the months or at the beginning of sentences.

\subsubsection{Phonological differences and lack of phonological knowledge}

Interestingly most of the phonemes of English are available in Kurdish except / $/$ / and / $ð /$, yet they are not problematic in terms of pronunciation for Kurdish learners due to their familiarity with those two phonemes in Arabic studying at school. Hence Kurdish EFL learners very unlikely to change a letter from a word due to lack of the phoneme of that letter in Kurdish as the Arabic learners of English do by replacing /p/ to /b/ in words like <bicture > for <picture> (Al-Jarf, 2009), nor like Japanese to substitute /l/ with /r/ or /v/ with /b/ as in <negrect> for 
<neglect> or <biolin> for <violin> (Gunion, 2012). However, the phoneme grapheme correspondence in English has caused serious problems for most of the English learners and Kurdish EFL learners in particular, since Kurdish is a phonetic language as it is written the way it is said (Rahimpour and Dovaise, 2011) and thus it has a transparent sound based writing system whereas English does not have one to one grapheme-phoneme correspondence and it is less transparent as it has complex spelling rules that need to be learnt Cook and Bassetti, 2005; Cook, 2008). For instance on phoneme in English can be represented in various graphemes such as $/ \mathrm{f} / \mathrm{can}$ be $\langle\mathrm{sh}\rangle,\langle\mathrm{si}\rangle,\langle\mathrm{ssu}\rangle,\langle\mathrm{ssi}\rangle,\langle\mathrm{ch}\rangle,\langle\mathrm{ti}\rangle,\langle\mathrm{ci}\rangle,\langle\mathrm{su}\rangle,\langle\mathrm{xu}\rangle,\langle\mathrm{xi}\rangle$ as in /shoe, tension, assure, passion, machine, action, social, sure, luxury, anxious. Whereas, in Kurdish one letter corresponds to one phoneme for instance / $/$ / corresponds to on letter which is / $/ /$. Hence, it has been noticed that Kurdish university students made many mistakes due to lack of phoneme and grapheme correspondence as in spelling errors of grapheme substitution like <bleim> for <blame>, <laide> for <lady>, <fiar> for <fire>and <rijen> for <region> or perhaps because of their mispronunciation of certain words for instance $<$ favourite $>$ have been misspelled in a variety of ways according to the students' pronunciation $<$ faivarut $>,<$ faivurat $>,<$ favaret $>$, $<$ favorete $>$ and <faivarit $>$.

\subsubsection{Lack of morphological and orthographical knowledge in English}

Many examples of misspelling found in the collected samples of the Kurdish first year university students, were made owing to lack of English morphological rules such as <maked> for <made> or <spented $>$ for <spent $>$ as well as adding (ed) for an adjective as in <happyed $>$. In addition some misspelled words were those whose final letter need to be doubled while inflectional or derivational suffixes added to them but they have not been doubled such as in <finaly> for <finally>, <begining> instead of <beginning> and <shoping> for <shopping>.

Another common spelling error identified from Kurdish EFL learners' compositions were leaving out the silent (e) as in $\langle$ mak $\rangle$ for $\langle$ make $\rangle,\langle$ com $\rangle$ for $\langle$ come $\rangle$, $\langle$ befor $\rangle\langle$ before $\rangle$, $<$ chang $><$ change $>,<$ fir $><$ fire $>$, <evry $><$ every $>$ and its silence might be the cause of being left unwritten. They tend to be unaware that the final (e) has several functions in English such as changing the letter $<\mathrm{a}>$ in $<$ make $>$ into the phoneme /ei/ not $/ \mathfrak{x} /$. Secondly, to show that letter $\langle\mathrm{c}\rangle$ is pronounced as $/ \mathrm{s} /$ not $/ \mathrm{k} /$ at the end of a word as in $\langle$ piece $\rangle$. Thirdly, to demonstrate that the final $\langle s\rangle$ is part of the original word not an inflectional suffix as in <course and horse $>$. Finally, to meet the required number of letters in a content word in English such as <tone, bone, gone, done>.

The final types of spelling errors are related to orthographic errors identified in consonant doubling, vowel and consonant omission and transposition. The doubling of consonant letters have been found in the collected samples of this study in <winnter, lunnch usefull, beautifull, nationall, persson>. This type of spelling mistakes is regarded as one of the common mistakes occurring in English (Carney, 1994). Carney (ibid) believes that doubling has caused difficulty for English language learners and even for its native users. The other types of spelling errors such as transposition and omission of both vowels and consonants can be attributed to the Kurdish college students' limited knowledge of English spelling rules. Some examples of 
transposition are <firend or freind for friend, tow-two, wief- wife, naem-name, WedensdyWednesday>. This types of misspelling is due to uncertainty and confusion of spellers who are not sure which element of a word to choose (ibid). Finally, the commonest and the most frequent type of spelling errors in this study has been omission (25.3\%) of all spelling errors which includes both vowel and consonant omissions by first year Kurdish university students, consonant omissions were only $(15 \%)$ as in <govermnet-government, enviromentenvirronment, blak-black>, whereas, vowel omission were $(85 \%)$ of all omission types of spelling errors made by Kurdish college students as in <frind-friend, intresting-interesting, diffrent-different, beutiful-beautiful, serch-search>. The possible causes behind making such mistakes by the Kurdish EFL leaners at university level may be due to several factors such as having an extra letter in a word as in <black> or silent letter as in <interesting >, <different> or mispronunciation as in <environment> and <government> the latter examples are usually mispronounced by the targeted sample students as they did not pronounce /n/ phoneme in those two words and thus they did not write it. Hence students need to be aware of phonological and vocabulary knowledge despite orthographic knowledge as according to Wasowicz (2007) they all are components of spelling knowledge.

\section{Conclusion}

In conclusion, misspelling is seemed to be one of the pervasive mistakes in the written tasks of first year Kurdish university students. The reason behind the widespread of spelling errors might refer to several factors such as the irregularity and inconsistency of English writing system, the difference between English and Kurdish writing systems, the negative interference of the Kurdish writing system into English writing tasks and the lack of phonological, morphological and orthographical knowledge and awareness of English by Kurdish university students. Eight categories of spelling errors have been identified in this study and the highest rate of misspelling words were omission type with the proposition of (85\%) vowel omission and only (15\%) are consonant omission. Among various types of spelling errors, inaccuracy in spelling vowels have been highly pervasive in the Kurdish university students' written works. The main cause of spelling errors by Kurdish learners of English are probably due to the grapheme-phoneme correspondence as in Kurdish is one to one except a few cases whereas in English the grapheme-phoneme correspondence is one to many and thus it has posed serious problems for Kurdish EFL learners in English spelling performance. Hence, having identified types of spelling mistakes and their underlying causes in this study might be helpful for practitioners and instructors to assist their students to deal with English spelling and teach those spelling rules of English to Kurdish university students that they seem to have most difficulty in them. In addition spelling instructions need to be integrated into both writing and reading classes so that the targeted students see each other's spelling errors and avoid making repeated spelling errors in English. 


\section{Reference}

Abdullah, S. \& Aram, K. (2004). English-Kurdish (Sorani) and Kurdish (Sorani)-Dictionary. India: Star publication/Languages of World Publication.

Akamatsu, N. (2003). The Effects of First Language Orthographic Features on Second Language Reading in Text. Language Learning 53: pp. 207-231.

Al-Hassan, A. (2011). English spelling is chaotic: What facts lie behind this popular judgment? [Online]. Available from: http://iatefl.britishcouncil.org/2011/sessions/2011-0417/english -spelling -chaotic-what-facts-lie-behind-popular-judgment. [Accessed 2 April 2014].

Al-Jarf, R. (2010). Spelling error corpora in EFL. Sino-US English Teaching, 7(1), pp. 6-15.

Al Jayousi, M. T., (2011). Spelling errors of Arab students: types, causes, and teachers' responses. Thesis (Master). The American University of Sharjah.

Altmann, G., \& Fengxiang, F. (Eds.). (2008). Analyses of script: properties of characters and writing systems (Vol. 63). Berlin: Walter de Gruyter.

Baron, N., (2005). The written turn. English Language and Linguistics, 9(2), pp. 359- 376.

Birch, B., (2007). English L2 Reading: Getting to the Bottom. Mahwah, New Jersey:

Lawrence Erlbaum Associates.

Brown, A. (1988). A Singaporean Corpus of Misspellings: Analysis and Implications. Journal of the Simplified Spelling Society, 3, pp.4-10.

Brown, H. D. (2000). Principles of language learning and teaching (4 th. ed.). White Plains, NY: Pearson Education.

Carney, E., (1994). A Survey of English Spelling. London: Routledge Inc.

Cook, V., (1997). L2 Users and English Spelling. Journal of Multilingual and Multicultural Development, 18(6), pp.474-488. 
Cook, V., (2004). The English Writing System. London: Arnold.

Cook, V. (2008). Second Language Learning and Language Teaching (4th ed.).

London: Hodder Education.

Cook, V. and Bassetti, B., (2005). An introduction to researching second language writing systems. In: Cook, V. and Bassetti, B., eds. Second Language Writing System. Clevedon: Multilingual Matters, pp. 1-61.

Corder, S. P. (1981). Error analysis and interlanguage. Oxford: Oxford University Press.

Coulmas, F., (2003). Writing Systems: An Introduction to their Linguistic Analysis. Cambridge: Cambridge University Press.

Crystal, D., (2003). The Cambridge Encyclopedia of the English Language. Cambridge: Cambridge University Press.

Catach, N. (1988). Quoted In: Perfetti, C.A., Rieben, L. and Fayol, M. (1997) eds. Learning to Spell: Research, Theory, and Practice Across Languages. Mahwah, New Jersey: Lawrence Erlbaum Associates. pp. 3-6.

Esmaili, K. S., \& Salavati, S. (2013). Sorani Kurdish versus Kurmanji Kurdish: An Empirical Comparison. In Proceedings of the 51st Annual Meeting of ACL.

Daneshfar, F., Barkhoda, W., \& Azami, B. Z. (2009). Implementation of a Text-toSpeech System for Kurdish Language. Paper presented at the meeting of Digital Telecommunications of Fourth International Conference on, Santaj/ Iran, July.

Fagerberg, I., (2006). English spelling in Swedish secondary schools: Students' attitudes and Performance [online]. Karlstads University Press. Available from: http:// kau.divaportal.org/smash/get/diva2.../FULLTEXT01.pdf [Accessed 18 March 2014]

Frost, R. (1992). Orthography and phonology: The psychological reality Of Orthographic depth. In M. Noonan, P. Downing \& S. Lima (eds.). The linguistics of literacy. Amsterdam: Benjamins. pp. 255-274.

Gunion, R. (2012). What are the types and proportions of Major spelling errors made by short stay Japanese university students enrolled full-time at Newcastle University? Annual Review of Education, Communication \& Language Sciences, 9. pp. 15-41

Hassanpour, A. (1992). Nationalism and language in Kurdistan, 1918-1985 (p. 343). San Francisco: Mellen Research University Press.

Hassanpour, A., Sheyholislami, J., \& Skutnabb-Kangas, T. (2012). Introduction. Kurdish: Linguicide, resistance and hope. International Journal of the Sociology of Language, (217):118. 
Henderson, L. (1981). Orthography and word recognition in reading. London: Academic Press inc.

Holligan, C. and Johnston R.S., 1991. Spelling errors and phonemic segmentation ability: the nature of the relationship. Journal of Research in Reading [online], 14 (1), 21-32.

Koda, K. (2005) Insights into second language reading. New York: Cambridge University Press,

Lado, R., (1964). Language Teaching, a Scientific Approach. New York: McGraw-Hill.

Mc Carus, E.N. (1992). Kurdish. In W. Bright (Ed.), International encyclopaedia of linguistics. (pp. 289-294). Oxford: Oxford University Press.

Matras, Y., \& Reershemius, G. (1991). Standardization beyond the state: the cases of Yiddish, Kurdish and Romani. Von Gleich and Wolff, 1991, 103-123.

Okada, T., (2005). A Corpus-based Study of Spelling Errors of Japanese EFL Writers with Reference to Errors Occurring in Word-initial and Word-final Positions. In: V.Cook and B.Bassetti, eds. 2005. Second Language Writing Systems. Clevedon: Multilingual Matters. pp. 164183.

Perfetti, C., Rieben, L. and Fayol, M. (1997). Learning to spell. Learning to Spell: Research, Theory, and Practice. Mahwah: Lawrence Erlbaum Associates.

Rahimpour, M., \& Dovaise, M. S. (2011). A Phonological Contrastive Analysis of Kurdish and English. International Journal of English Linguistics, 1(2). 73-82

Sampson, G., (1985). Writing Systems: A Linguistic Introduction. Stanford, California: Stanford University Press.

Saville-Troike, M., 2006. Introducing second language acquisition. Cambridge: Cambridge University Press.

Smedley, D. (1983). Teaching the basic skills: spelling, puctuation, and grammar in secondary English. New Fetter Lane London: Methuen and co. Ltd

Sproat, R., (2000). A Computational Theory of Writing Systems. Cambridge: Cambridge University Press.

Soltani, R. (2005). (ريّزمانى كوردى Kurdish Grammar), 1st (ed), Sanandaj: Soma (In Kurdish).

Swan, M., and Smith, B., (2001). Learner English: A teachers' guide to interference and other problems. Cambridge: Cambridge University Press.

Tonga, X. et al., (2009). Morphological Awareness, Orthographic Knowledge, and Spelling 
Errors: Keys to Understanding Early Chinese Literacy Acquisition. Scientific Studies of Reading. 13 (5), 426-452.

Van Berkel, A., (2005). The role of the phonological strategy in learning to spell in English as a second language. In: Cook, V. and Bassetti, B., eds. Second Language Writing System. Clevedon: Multilingual Matters, pp. 97-121.

Wasowicz, J., 2007. What do spelling errors tell us about language knowledge? Available from: http://www.learningbydesign.com/uploads/What_Do_Spelling_Errors_Tell_Us_Language_Knowledge.pdf [Accessed on 5 April, 2014].

Wing, A.M. and Baddeley, A.D., (1980). Spelling errors in handwriting: A corpus and a distributional analysis. In: Frith, U., ed. Cognitive Processes in Spelling. London: Academic Press, pp. 251-285.

\section{Appendix 1, the collected spelling errors made by Kurdish college students}

\begin{tabular}{|l|l|l|l|l|l|l|l|l|}
\hline & & & & & \\
\end{tabular}




\begin{tabular}{|c|c|c|c|c|c|c|c|c|c|}
\hline 9 & pleace & & & & $\begin{array}{l}\text { Fiar- } \\
\text { fire }\end{array}$ & foot ball & june & & 4 \\
\hline 10 & lunnch & specal & picnik & & & $\begin{array}{l}\text { break } \\
\text { fast }\end{array}$ & march & & 5 \\
\hline 11 & & fir (fire) & $\begin{array}{l}\text { Nessesar } \\
y \text {, fanny- } \\
\text { funny }\end{array}$ & & & $\begin{array}{l}\text { Sun } \\
\text { flower }\end{array}$ & kurdish & & 5 \\
\hline 12 & caluture & Finaly & & & $\begin{array}{l}\text { Fiar- } \\
\text { fire }\end{array}$ & $\begin{array}{l}\text { Grand } \\
\text { mother }\end{array}$ & march & & 5 \\
\hline 13 & & resturand & resturand & & & $\begin{array}{l}\text { Grand } \\
\text { mother }\end{array}$ & $\begin{array}{l}\text { Family } \\
\text { There, } \\
\text { march }\end{array}$ & & 6 \\
\hline 14 & & $\begin{array}{l}\text { goverme } \\
\text { nt } \\
\text { vollyball }\end{array}$ & & & frut & allot, & & colegge & 5 \\
\hline 15 & familly & $\begin{array}{l}\text { Cath- } \\
\text { catch }\end{array}$ & & & & upearly & march & & 4 \\
\hline 16 & & $\begin{array}{l}\text { Mak, } \\
\text { blak }\end{array}$ & & & & ataxi & march & & 4 \\
\hline 17 & & $\begin{array}{l}\text { tak, } \\
\text { Intristing } \\
\text {, }\end{array}$ & $\begin{array}{l}\text { Intristing } \\
\text { relashion }\end{array}$ & freind & & anice & & & 6 \\
\hline 18 & Faire-fire & frend & pecnic & & $\begin{array}{l}\text { Fiar- } \\
\text { fire }\end{array}$ & & $\begin{array}{l}\text { march, } \\
\text { friday }\end{array}$ & & 6 \\
\hline 19 & & $\begin{array}{l}\text { Visted, } \\
\text { frind, }\end{array}$ & viseted & & $\begin{array}{l}\text { Kot- } \\
\text { coat }\end{array}$ & $\begin{array}{l}\text { grand } \\
\text { mother }\end{array}$ & march & $\begin{array}{l}\text { pronounsa } \\
\text { tion }\end{array}$ & 7 \\
\hline 20 & & com & $\begin{array}{l}\text { Slepp- } \\
\text { slept, } \\
\text { entarnet, }\end{array}$ & & & & My & & 4 \\
\hline 21 & & $\begin{array}{l}\text { Shoping, } \\
\text { continou } \\
\mathrm{s}\end{array}$ & becouse & firend & & $\begin{array}{l}\text { Break } \\
\text { fast }\end{array}$ & $\begin{array}{l}\text { My, } \\
\text { Mother, } \\
\text { Music }\end{array}$ & maked & 9 \\
\hline 22 & & $\begin{array}{l}\text { Pajes, } \\
\text { studed }\end{array}$ & Unkle, & & $\begin{array}{l}\text { Laide- } \\
\text { lady }\end{array}$ & & & Favouret & 5 \\
\hline 23 & & $\begin{array}{l}\text { geting, } \\
\text { shoping }\end{array}$ & & & & $\begin{array}{l}\text { break } \\
\text { fast, } \\
\text { asong, } \\
\text { amusic }\end{array}$ & $\begin{array}{l}\text { Newspape } \\
\mathrm{r}\end{array}$ & & 6 \\
\hline 24 & spented & $\begin{array}{l}\text { Frend, } \\
\text { visted, } \\
\text { uneverst } \\
\text { y finaly }\end{array}$ & $\begin{array}{l}\text { Dormitar } \\
\mathrm{y},\end{array}$ & & & & & uneversty & 7 \\
\hline
\end{tabular}




\begin{tabular}{|c|c|c|c|c|c|c|c|c|c|}
\hline 25 & & $\begin{array}{l}\text { brekfast, } \\
\text { enjyed }\end{array}$ & & $\begin{array}{l}\text { Frist, } \\
\text { buoght }\end{array}$ & $\begin{array}{l}\text { fainal } \\
\mathrm{y}\end{array}$ & anice, itis & My & & 8 \\
\hline 26 & & & $\begin{array}{l}\text { Emporta } \\
\text { nt, } \\
\text { becouse }\end{array}$ & & $\begin{array}{l}\text { fainal } \\
\mathrm{y}\end{array}$ & anice & Family & happyed & 6 \\
\hline 27 & & $\begin{array}{l}\text { Vollyball } \\
\text { continou } \\
\mathrm{s}\end{array}$ & doughter & & & $\begin{array}{l}\text { home } \\
\text { work }\end{array}$ & $\begin{array}{l}\text { march, } \\
\text { brother }\end{array}$ & & 6 \\
\hline 28 & & beutiful & rever & & & Itis & Me, My & & 5 \\
\hline 29 & & til & $\begin{array}{l}\text { footboll, } \\
\text { bock, } \\
\text { hume }\end{array}$ & wief & & & cloThes & & 6 \\
\hline 30 & & $\begin{array}{l}\text { Langueg, } \\
\text { befor }\end{array}$ & $\begin{array}{l}\text { Beggest, } \\
\text { Langueg }\end{array}$ & & & $\begin{array}{l}\text { some } \\
\text { time }\end{array}$ & There & & 6 \\
\hline 31 & $\begin{array}{l}\text { usefull, } \\
\text { nationall }\end{array}$ & $\begin{array}{l}\text { chang, } \\
\text { envirome } \\
\text { nt }\end{array}$ & & & & & friday & & 5 \\
\hline 32 & & $\begin{array}{l}\text { regin, } \\
\text { trafic }\end{array}$ & $\begin{array}{l}\text { Ferst, } \\
\text { fastival }\end{array}$ & & $\begin{array}{l}\text { Rijen- } \\
\text { region }\end{array}$ & $\begin{array}{l}\text { Out side, } \\
\text { apicnic, }\end{array}$ & & & 7 \\
\hline 33 & $\begin{array}{l}\text { freesh, } \\
\text { persson }\end{array}$ & $\begin{array}{l}\text { begining, } \\
\text { receved }\end{array}$ & & & & & $\begin{array}{l}\text { Year, At, } \\
\text { New, City }\end{array}$ & & 8 \\
\hline 34 & $\begin{array}{l}\text { mounth, } \\
\text { espectially }\end{array}$ & serch & ganeral & & & apicnic & Popular & & 6 \\
\hline 35 & & & studyed & Tow-two & $\begin{array}{l}\text { Faivar } \\
\text { it, } \\
\text { bleim, }\end{array}$ & & $\begin{array}{l}\text { Meat, } \\
\text { Main } \\
\text { Meantime }\end{array}$ & & 7 \\
\hline 36 & beutifull & beutful & $\begin{array}{l}\text { happenes } \\
\mathrm{s} \text {, wither, } \\
\text { brather }\end{array}$ & & & $\begin{array}{l}\text { apicnic, } \\
\text { out side }\end{array}$ & & $\begin{array}{l}\text { Turest } \\
\text { villeg }\end{array}$ & 9 \\
\hline 37 & Preapared & $\begin{array}{l}\text { Weathe, } \\
\text { finaly }\end{array}$ & & specail & & $\begin{array}{l}\text { goto, } \\
\text { apicnic }\end{array}$ & First & & 7 \\
\hline 38 & & $\begin{array}{l}\text { daly, } \\
\text { befor }\end{array}$ & owt, nise & & & apicnic & & faivurat & 6 \\
\hline 39 & & $\begin{array}{l}\text { diffrent, } \\
\text { midle }\end{array}$ & & & & $\begin{array}{l}\text { Apicnic, } \\
\text { itis }\end{array}$ & & & 4 \\
\hline 40 & & attrative & resk & & & $\begin{array}{l}\text { alot, } \\
\text { alittle }\end{array}$ & The, My & nissesary & 7 \\
\hline
\end{tabular}

